\title{
Design and Use of Management Accounting and Control Systems in the Jordanian Universities
}

\author{
Dr. Hussien Ahmad Al-Tarawneh \\ mmhad57@yahoo.com \\ Phone: 00962-777466635 \\ Mania Moyad Mubaslat(Corresponding author) \\ maniamub@yahoo.com \\ Phone: 00962-777590180
}

Received: July 14, 2011 Accepted: September 29, $2011 \quad$ DOI: 10.5296/ijafr.v1i1.773

\begin{abstract}
A survey was conducted for professors at different faculties in addition to focus groups and interviews for both deans and students at different Jordanian Universities. Four randomly selected Universities (2 Public Universities and 2 Private Universities) 30 professors and 150 students from different faculties were the sample of the study to ascertain the views of management accounting systems utilization in the higher educational sector in Jordan, and the skills and competencies of recent graduates.

The results showed that students placed an emphasis on the absence of Management Accounting System in their faculties, while academics placed an emphasis on experience in higher education to apply Control Management Systems. Both groups were in agreement on the quality of education required of recent graduates.
\end{abstract}

Keywords: Management control systems, Management Accounting, Higher Education in Jordan, university faculties. 


\section{Introduction}

Globalization and the increasing complexity of business, together with high powered computing technology, have contributed to the development of new management accounting techniques. As these new techniques develop and sit alongside existing ones, attention focuses on what should form part of a 'common body of knowledge for management accounting in education. Existence of a possible 'gap' in management accounting between theory and practice may indicate that academics are not teaching the latest techniques or are not teaching the traditional methods still in use (Scapens, 1983; Novin, Pearson \& Senge, 1990). The identification of the existence of a 'gap' may assist students and academics in determining the nature of that gap and how to close it. This paper aims to focus on the utilization of management accounting in different commercial or industrial organizations. The management control systems (MCSs) are perceived as broad based systems that go beyond management accounting systems to embrace behavioral and cultural aspects of controls which, according to Kober et al. (2007), are more meaningful in the higher education sector.

The term Management accounting and control systems is rarely used in the educational system even though it has a strong connectivity with quality assurance and total quality management, and from here the importance of this study was raised to highlight the use of Management Accounting and Control System in the Jordanian Universities.

\section{Higher Education in Jordan}

Higher education along with primary and secondary education has been prioritized, to put Jordan on the road to intellectual development.(1)Higher education in Jordan began with the second half of the twentieth century, namely the sixties, when numerous Teachers' Colleges were established throughout the country. Their establishment provided the necessary teaching manpower needed to meet the high demand on school education characterizing that era. The first public Jordanian university, the University of Jordan, was established in 1962. Yarmouk University followed in 1976, and six more public universities were established in different parts of the Kingdom since that date. In 1989 the Council of Higher Education endorsed the first policy document authorizing the establishment of private universities. Amman University, the first Jordanian private university, was established in 1990. An impressive number of twelve more private universities were founded since that date. Non-university education is offered at Community Colleges, which were created in 1981 by converting and expanding the existent Teacher Colleges. These institutions are meant to offer specialized, career-oriented training, and prepare their students for work in middle-level professions. All community colleges are supervised by and affiliated to Al- Balqa Applied University, which is a Jordanian public university.

\section{The Ministry of Higher Education \& Scientific Research}

The Jordanian Council of Higher Education was established in 1982 in response to the need for regulation and planning of higher education policies and coordination among Jordanian public universities. The Council formed the core for the Ministry of Higher Education \& Scientific Research, which was established in 1985. The Ministry and the Council undertook 
the mission of applying the government's educational policies at post-secondary level, and of legislating up-to-date laws on higher education. The Ministry of Higher Education was annulled in 1998, but was re-established in August 2001 according to instructions by His Majesty King Abdullah II, and renamed as The Ministry of Higher Education and Scientific Research.

Jordan is ranked 90 out of 177 in the Human Development Index-Despite strained resources, the Ministry of Education developed highly advanced national curriculum and many other nations in the region have developed their education system using Jordan as a model. Jordan ranks number one in the Arab World. The Jordanian Ministry of Education is now making it mandatory for students to be computer literate and able to apply their studies in computers to their regular studies, most especially the scientific and mathematical courses. Its educational system is of international standards and its secondary education program is accepted in world-class universities.

\section{Educational Reform in Jordan}

The recent education reforms started in the early 1990s. This reform process was accelerated under His Majesty King Abdullah II in early 2001 with a vision to make Jordan the regional technology hub and an active player in the global economy. The National Vision and Mission for Education, as developed and endorsed in late 2002, states the desired direction for general education in the country. The two major consultative documents, that helped shape the national vision and also set directions for educational reform initiatives, were Jordan Vision 2020 and the 2002 Vision Forum for the Future of Education. These documents spanned kindergarten to lifelong continuing education. The overall strategy proposed by the Forum was endorsed by the Economic Consultative Council (ECC) in October 2002. The national development strategy and the Forum results were consolidated into specific development plans, the Social and Economic Transformation Plan, the General Education Plan 2003-08:

In July 2003, the Government of Jordan launched an ambitious program in the entire MENA region a 10 year multi-donor Education Reform for the Knowledge Economy Program (ErfKE) of which the World Bank provided US\$120 million. The goal of the program was to re-orient the education policies and programs in line with the needs of a knowledge based economy, improve the physical learning environment in most schools and promote early childhood education. This first phase of program is from 2003-2009, closing in June 2009.

The second phase of the ErfKE, which is aligned with IBRD and IFC Country Assistance Strategy (CAS) for the Hashemite Kingdom of Jordan, will be from 2009-2015. The aim of this program is to strengthen and institutionalize the reforms introduced under ERfKE I, with a particular focus on school level implementation and teacher quality. It will strengthen the institutional capacity of MoE in policy, strategic planning and monitoring and evaluation, and improve teacher employment, utilization and professional development policies and implementation. The program will also fine tune the curriculum and student assessment to ensure alignment with the knowledge based economy.

Jordan Education Initiative recently received the UNESCO prize on ICT use in Education. 


\section{Mll Macrothink}

International Journal of Accounting and Financial Reporting ISSN 2162-3082 2011, Vol. 1, No. 1

This pioneering education project in Jordan schools is based on utilizing the power of information and technology with the proven methods of learning to transform the learning environment in schools.

Just over $2.5 \%$ of Jordan's total population is enrolled at university, a proportion comparable to the United Kingdom. Access to higher education is open to holders of the General Secondary Education Certificate who can then choose between private Community Colleges, public Community Colleges or universities (public and private). The credit-hour system, which entitles students to select courses according to a study plan, is implemented at universities.

Higher education system of the country has evolved considerably in the past five years. But still a lot needs to be done to keep up with a rapidly growing knowledge based economy. In years between 2000/2001 and 2006/2007, Jordan has seen an increased demand for higher education with enrollments growing at an annual rate of 14 percent from 77,841 to 218,900 students. It has tertiary gross enrollment levels of about 40 percent which is higher than the regional average, as can be seen from the chart below. Three new public universities have been established recently reaching a total of 10 public universities in the country.

Private universities have seen a rapid increase in enrollments as well. Since 2000 to 2006, enrollment in 12 private universities grew by about 18 percent annually from 36,642 to 55,744. However, enrollment numbers in community colleges declined from 30,000 to 26,215 .This decrease in enrollment rates reflect a bias to a 4 year university education and also the fact that quality and level of training given in these colleges is not what is in demand in the labor market of a knowledge based economy. With increasing number of students going for the attainment of higher education, the government needs to allocate greater resources in improving the current higher education system and also to improve access of good universities for the rising population. Even the private universities have to change some of their admission policies. The enrollment cap in the private universities restricts the ability of university to absorb increasing number of higher education students. Projection for the number of students entering university is 92,000 per year by 2013 up from 50,469 in 2005

\section{Universities Level Studies}

First stage: Undergraduate level most universities in Jordan follow the English-American education systems and are associated with many American and English universities. Bachelor's Degrees normally take four years. In Dentistry, Pharmacy and Engineering, studies last for five years. In Medicine, they last for six years, followed by an Internship which lasts for one year. The Bachelor's Degree requires a total of 126-164 credit hours, depending on the field of study.

- Second stage: Postgraduate level A Master's degree is awarded after a further one to two years' study following a Bachelor's Degree. It can be obtained either by course work and a thesis (c. 24 credit hours of courses and nine credit hours of research), or by course work (c. 33 credit hours) and a comprehensive examination. There are other postgraduate degrees equivalent to the Master's degree in some Jordanian universities like the Magister in the 


\section{Macrothink}

International Journal of Accounting and Financial Reporting ISSN 2162-3082

German Jordanian University, the DEA's degree in the Universities which follow the French system and the MBA for the students who have significant work experience.

- Third stage: Doctorate A Doctorate Degree is awarded after three to five years of further study and the submission of an original dissertation. It requires, depending on the subject, 24 credit hours of course work and 24 credit hours of research.

- Teacher education: Training of pre-primary and primary/basic school teachers Basic schoolteachers must hold a Bachelor's Degree. Training of secondary school teachers: Secondary school teachers must hold a Bachelor's Degree and a one-year postgraduate Higher Diploma in Education. Training of higher education teachers: They must hold a Doctorate $(\mathrm{PhD})$. In some cases a Master's Degree is sufficient.

- Non-traditional studies: Distance higher education This type of education is offered at the newly established branch of the Arab Open University.

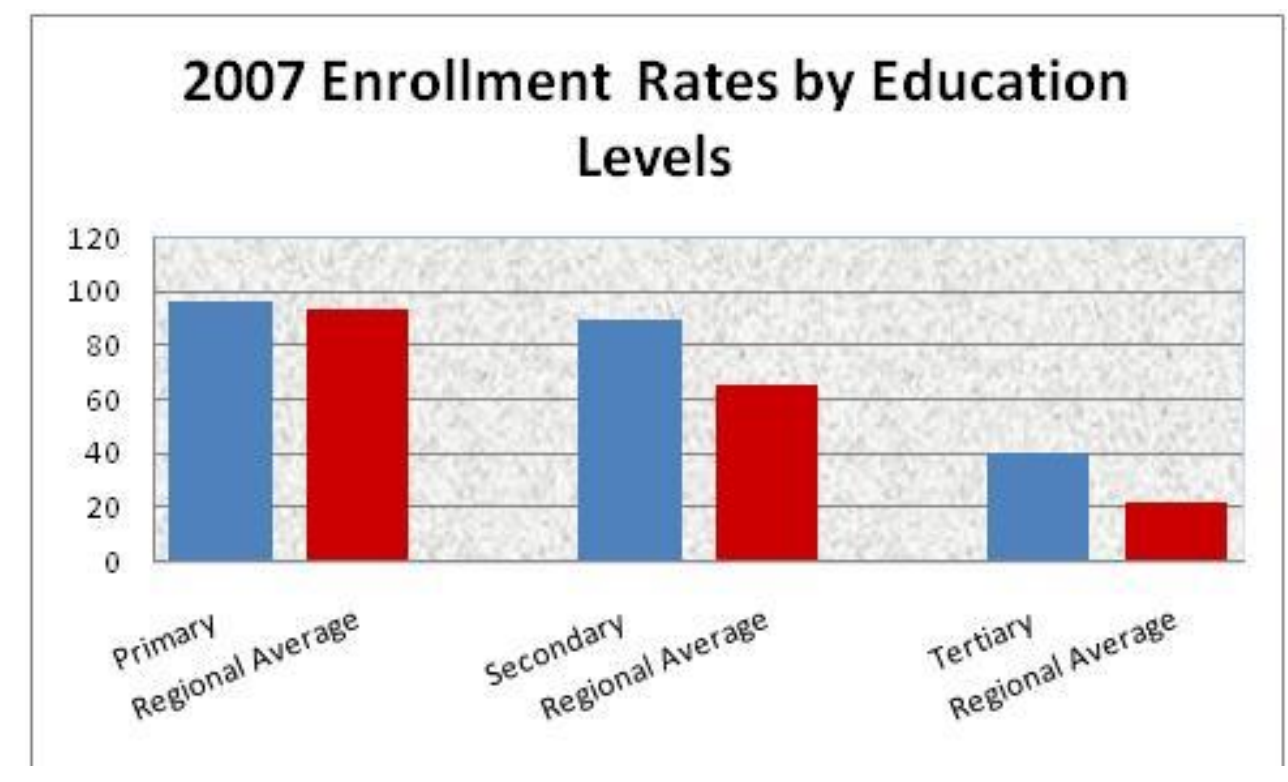

Source: UNESCO Institute for Statistics 2007

\section{The New Higher Education Law in Jordan}

Consequently, a new Law on Higher Education was endorsed: Law no. 41 for the year 2001, which cancelled the previous Law. By this law, a Ministry of Higher Education \& Scientific Research was established, and took over supervising all higher education issues, and includes the following Councils:

- The Higher Education Council (which comprises the Higher Committee for Scientific

Research)

- The Accreditation Council

The new Higher Education Law assigned the Ministry of Higher Education \& Scientific 


\section{Macrothink}

International Journal of Accounting and Financial Reporting

Research the following prominent functions:

1- Implementing the general policy of higher education in Jordan.

2- Coordinating between higher education institutions and public and private centers for consultations and research.

3- Signing cultural and scientific agreements in the field of higher education and scientific research.

4- Representing Jordan in international conferences and symposia on higher education.

5- Recognizing foreign institutions of higher education and equating certificates issued by them.

6- Setting student eligibility rules for scholarships inside and outside Jordan.

7- Following up the affairs of Jordanian students abroad through Jordanian cultural counselors.

The Law gave the Higher Education Council the following main functions:

1- Formulating the general policy of higher education in Jordan.

2- Endorsing the establishment of new higher education institutions.

3- Issuing instructions concerning administration and finance of the higher education sector.

4- Coordinating between local higher education institutions.

5- Evaluating the quality of higher education in terms of sufficiency and efficiency.

6- Determining the basic admission requirements at higher education institutions.

The Accreditation Council is given by the same law the following major duties:

1- Defining the regulations for the accreditation of higher education institutions, amending and developing them in light of the general policy of higher education.

2- Supervising the performance of higher education institutions and their commitment to applying the rules of accreditation.

3- Appointing the specialized committees needed to carry out the tasks of the Accreditations Council.

4- Ensuring that institutions of higher education reach their pre-defined goals through continuous evaluation of their programs.

5- Proposing schemes for regulations and rules of the Council's duties.

6- Publishing the decisions the Council takes concerning accreditation in the official media. 


\section{Macrothink \\ International Journal of Accounting and Financial Reporting \\ ISSN 2162-3082 \\ 2011, Vol. 1, No. 1}

\section{The concept of Management Accounting}

Management accounting or managerial accounting is concerned with the provisions and use of accounting information to managers within organizations, to provide them with the basis to make informed business decisions that will allow them to be better equipped in their management and control functions.

In contrast to financial accountancy information, management accounting information is:

- Forward-looking, instead of historical;

- Model based with a degree of abstraction to support decision making generically, instead of case based;

- Designed and intended for use by managers within the organization, instead of being intended for use by shareholders, creditors, and public regulators;

- Usually confidential and used by management, instead of publicly reported;

- Computed by reference to the needs of managers, often using management information systems instead of by reference to general financial accounting standards.

According to the Chartered Institute of Management Accountants (CIMA), Management Accounting is "the process of identification, measurement, accumulation, analysis, preparation, interpretation and communication of information used by management to plan, evaluate and control within an entity and to assure appropriate use of and accountability for its resources. Management accounting also comprises the preparation of financial reports for non-management groups such as shareholders, creditors, regulatory agencies and tax authorities" (CIMA Official Terminology).

The Institute of Management Accountants (IMA) recently updated its definition as follows: "management accounting is a profession that involves partnering in management decision making, devising planning and performance management systems, and providing expertise in financial reporting and control to assist management in the formulation and implementation of an organization's strategy."

The American Institute of Certified Public Accountants (AICPA) states that management accounting as practice extends to the following three areas:

- Strategic Management - advancing the role of the management accountant as a strategic partner in the organization.

- Performance Management — developing the practice of business decision-making and managing the performance of the organization.

- Risk Management-contributing to frameworks and practices for identifying, measuring, managing and reporting risks to the achievement of the objectives of the organization.

The Institute of Certified Management Accountants (ICMA), states "A management 


\section{MInstitute ${ }_{\text {Mink }}^{\text {Macrothink }}$}

International Journal of Accounting and Financial Reporting ISSN 2162-3082 2011, Vol. 1, No. 1

accountant applies his or her professional knowledge and skill in the preparation and presentation of financial and other decision oriented information in such a way as to assist management in the formulation of policies and in the planning and control of the operation of the undertaking." Management Accountants therefore are seen as the "value-creators" amongst the accountants. They are much more interested in forward looking and taking decisions that will affect the future of the organization, than in the historical recording and compliance (score keeping) aspects of the profession. Management accounting knowledge and experience can therefore be obtained from varied fields and functions within an organization, such as information management, treasury, efficiency auditing, marketing, valuation, pricing, logistics, etc.

Another definition is Management accounting is a specialized sub-set of accounting, focusing on internal needs of businesses. While financial accounting focuses on external reporting and history, management accounting focuses on current information and the needs of in-house management. Both management and financial accounting work together to give management and external users the information required. Often a management computer system feeds into a financial computer system, providing users and stakeholders with complete cost information.

Popular with manufacturing environments, management accounting focuses on assigning costs to processes. Instead of dealing with debits and credits, accounts or financial statements, as financial accounting does, management accounting quantifies details, quality controls, and expectations. Cost Accounting is one of the main principles of management accounting. It is used to determine budgets, costs, and profitability of products or departments.

Many of the practices that are now known as management accounting were thought of as unreliable or impractical in the first half of the $20^{\text {th }}$ century. Robert N. Anthony has seen much change throughout his years in accounting. In his article he walks us through the many stages of growth that management accounting has undergone in the last approximately one hundred years.

He starts his story by telling about practices that were used in many large companies in the nineteenth century. Practices such as standard costs, overhead rates, opportunity cost, and profit centers. He goes on to talk about how these and other items that we now know of as part of management accounting showed up in early accounting books. These practices were not first thought of as the broad subject now called management accounting, instead they were in the business curriculum as part of cost accounting. Very few institutions actually taught courses in management accounting in the early nineteen hundreds. Anthony talked some about a Professor he had at Harvard who covered the topics in a course titled Budgetary Controls in the thirties and forties. After the second World War Anthony, as a new assistant professor, was asked to build cases and notes for a new accounting course on management accounting that was included in the major curriculum changes at Harvard Business School. In 1954 Anthony submitted his notes to a publisher with the hopes of compiling them into a management accounting book. This book and a few others released at the same time are what Anthony credits as the beginning of management accounting. 


\section{Mll Macrothink}

International Journal of Accounting and Financial Reporting ISSN 2162-3082 2011, Vol. 1, No. 1

At the time when management accounting courses first appeared they differed from what was being taught as cost accounting at the time in two main ways. First was the human aspect of the numbers which (the old) cost accounting overlooked. Management accounting took into account the idea that the end numbers were used by people to make decisions including how accounting information could influence behavior. The second difference was that cost accounting focused mainly on full costing (finding the true cost) while management accounting covered a much broader range of topics.

Management accounting as a topic distinct from cost accounting continued to gain acceptance through developments such as; the National Association of Cost Accountants dropping "Cost" from their name, changing the NAA magazine title to Management Accounting, and the NAA establishment of a Certificate of Management Accounting similar to the CPA exam. Also was the formation of the Committee on Cost Concepts and Standards by the American Accounting Association in 1954. This committee came to a three-part classification of cost information. The report, "Tentative Statement of Cost Concepts Underlying Reports for Management Purposes", was published in 1956. This report included three classifications called, "full cost", differential cost", and responsibility cost".

\section{The concept of Management Control Systems}

Management control systems are perceived as a mechanism to increase the likelihood for an organization to 1) achieve its objectives and 2) utilize resources efficiently when implementing strategies.

Additionally, the management control system can become an early warning system for feeding back information to the strategic planning and control system. Alternatives to management accounting are introduced but the main focus is on financial results control systems ranging from planning and budgeting models to balance scorecards.

Management Control Systems (MCSs) help organizations to increase the potability that employees make decisions and take actions which are in the organizations best intrest(Chow,Shields\&ww,1999). It has to be noted that some authors use the term management control in a narrow perspective and use the term organizational control for broader view. ( Chenhall,2003). There are various management Control elements or systems such as accounting Control or non- accounting controls like behaviour and clan controls. (Ouchi,1980).

A study for Bob\& Taylor (2010) investigates the diagnostic versus interactive uses of management control systems by Deans/Pro-Vice Chancellors of Faculties/Colleges (hereafter called Faculty PVCs). It seeks to identify how the professional and experiential characteristics of these senior academic executives and the structure of their Faculty, impact on their managerial and collegial orientation as reflected in their approach to using management controls. A mail survey of Faculty PVCs is conducted amongst a census of all Faculties/Colleges of all universities in Australia. Supplementing this survey are semi-structured interviews with the PVC of the business and science Faculty at a large Australian university. Results reveal that PVCs who have had a longer career in higher 
education tend to use MCSs more interactively (or collegially). There is also evidence that as PVCs hold their current position for longer periods; they tend to move from an early diagnostic use of MCSs to a subsequent interactive use. Further, the higher the complexity of a Faculty the more a PVC will adopt an interactive approach to MCS use. Other PVC and Faculty characteristics did not reveal patterns of significant influence on the interactive or diagnostic use of MCSs. A key revelation from interviews is that PVCs will give over-riding importance to meeting centrally-set diagnostically-focused KPI, but still take a collegial approach within their Faculty to the broader use of MCSs. The findings lend limited support to upper echelons theory, but provide a grounding for further research into the impact that a managerial versus a collegial approach by PVCs/Deans may have on their Faculty's growth in innovative capacities, teaching qualities or financial strength.

\section{Methodology}

The sample size was 50 faculties in four Jordanian Universities ( 2Public Universities and 2 Private Universities. 30 professors and 150 students from different faculties were the sample of the study to ascertain the views of management accounting systems utilization in the higher educational Sector in Jordan, and the skills and competencies of recent graduates.

\section{The Evaluation tools deployed were:}

1. Students Focus Groups: around 10 students selected randomly to discuss their experiences about the utilization of Management Control Systems (MCSs) in their universities and faculties, the focus groups were semi-structured and left a good space for the students to express their feeling and attitudes.

2. Professors' interviews: the interviews were semi-structured to allow capturing unanticipated factors and results, 15 professors have been interviewed to discuss their opinion of using Management Accounting and Control Systems in their faculties and the noticeable effect on both professors and students.

3. A survey was developed. A questionnaire has been designed and distributed; the questions tackled the Professors \& students' trends and attitudes in using Management Accounting in their faculties plus open ended questions regarding negative and positive sides.

\section{Results of the Study}

Based on a quantitative and qualitative analysis, the following results were pointed:

- Professors who have lower experience in higher education tend to use Management Control System more than those who have long experience.

- Both Professors and students believe in the importance of performance in teaching and research skills toward obtaining and mastering the $21^{\text {st }}$ Century Skills.

- Both Professors and Students emphasized on the quality of education required of recent graduates. 


\section{Macrothink}

International Journal of Accounting and Financial Reporting ISSN 2162-3082

- The professors showed fully understanding of the university's vision and strategic plan but when it comes to practice, few are applicable.

- The students highlight the traditional teaching pedagogies which don't reflect their needs and according to them this is due to the lack of Management Accounting and Control Systems utilization.

\section{Recommendations}

This paper considers the utilization of management Accounting and Control Systems in the Jordanian Universities, and to evaluate to what extent it is used in real. The paper also compares the skills that students and academics believe are important for recent graduates and what both groups perceive to be the strengths and weaknesses of recent graduates. It is recommended to recruit professors with little experience in higher education, in addition to adopting new pedagogies. On the other hand the concept of Management Accounting and Control Systems was not familiar to some participants in the target group (Study Sample). Further studies are recommended in this field.

\section{References}

1. A paper by Professor Ahmad Abu-El-Haija, Coordinator, National TEMPUS Office Jordan.

2. Aberenthy, M.A.,\& Chua,W.F. (1996). A field study of control system"redesign" the impact of institutional processes on strategic choice. Contemporary Accounting Research,13(2).

3. Anthony, R. N. 1989. Reminiscences about management accounting. Journal of Management Accounting Research (1): 1- 20

4. Birnberg, J. G. 1992. Managerial accounting: Yet another retrospective. Advances in Management Accounting

5. Bobe, Belete, and Taylor, Dennis, (2010) "Use of management control systems in university faculties: evidence of diagnostic versus interactive approaches by the upper echelons",

6. Chenhall,R.H.(2003). Management Control system design with its organizational context: findings from contingency based research and directions for the future. Accounting Organizations and Society, 28(2/3)

7. Chow,C.W.,Shields, M.D.,\&Wu,A.(1999). The importance of national culture in the design of and preference for management controls for multi-national operations. Accounting Organizations and Society. 24(5/6)

8. Elnicki, R. A. 1971. The genesis of management accounting. Management Accounting

9. Friedl, Gunther; Hans-Ulrich Kupper and Burkhard Pedell (2005). "Relevance Added: Combining ABC with German Cost Accounting". Strategic Finance (June): 56-61. 


\section{Mll Macrothink}

International Journal of Accounting and Financial Reporting ISSN 2162-3082 2011, Vol. 1, No. 1

10. Kilger, Wolfgang (2002). Flexible Plankostenrechnung und Deckungsbeitragsrechnung. Updated by Kurt Vikas and Jochen Pampel (12th ed.). Wiesbaden,Germany: Gabler GmbH.

11. Kober, R., Ng, J., and Paul, B. J. 2007. The interrelationship between management controlmechanisms and strategy. Management Accounting Research 18 (4):425-452.

12. Novin, A.M., Pearson, M.A., \& Senge, S.V. (1990). Improving the curriculum for aspiring management accountants: The practitioner's point of view. Journal of Accounting Education, 8, 207-224.

13. "Taking Control of IT Costs". Nokes, Sebastian. London (Financial Times / Prentice Hall): March 20, 2000.

14. Sharman, Paul A. (2003). "Bring On German Cost Accounting". Strategic Finance (December): 2-9.

15. Scapens, R.W. (1983). Closing the gap between theory and practice. Management Accounting; London. 61, (10), 34-36.

16. http://www.nature.com/nature/journal/v444/n7115/full/444026a.html

17. "World Bank. 2009. "Education Reform for the Knowledge Economy II." Project Information Document. World Bank, Washington ,DC". http://www-wds.worldbank.org/external/default/WDSContentServer/WDSP/IB/2009/ 01/30/000104615_20090203101235/Rendered/PDF/JO010ERfKE0II01aisal0Stage01 0Jan.28.pdf.

18. "United Nations 2006". http://hdr.undp.org/en/media/HDI_2008_EN_Tables.pdf.

19. "World Bank 2009. "Education Reform for Knowledge Economy II Project.” Project Appraisal Document.pp4". http://www-wds.worldbank.org/external/default/WDSContentServer/WDSP/IB/2009/ 05/04/000333038_20090504003729/Rendered/PDF/468240PAD0P105101Official0U se0Only1.pdf.

20. "USAID in Jordan 2009". http://jordan.usaid.gov/jordan.cfm.

21. "World Bank MENA external website". http://web.worldbank.org/WBSITE/EXTERNAL/COUNTRIES/MENAEXT/EXTMN ASUMMNSHD/0,,contentMDK:22116832 pagePK:51246584 piPK:51241019 theS itePK:2013988,00.html.

22. "World Bank blog,2010". http://twitter.com/WBedutech.

23. "Jordan Education Initiative". http://www.jei.org.jo/.

24. "World Bank 2003.Education Reform for Knowledge Economy I, Project Appraisal Document(PAD)".

http://wwwwds.worldbank.org/external/default/WDSContentServer/WDSP/IB/2003/0 
5/10/000094946_03043004015982/Rendered/PDF/multi0page.pdf.

\section{UNESCO}

26. "Government of Hashemite Kingdom of Jordan". http://www.kinghussein.gov.jo/jo_information.html.

27. "World Bank. 2009. "Education Reform for the Knowledge Economy II." Project Information Document. World Bank, Washington ,DC". http://imagebank.worldbank.org/servlet/WDSContentServer/IW3P/IB/2009/01/30/000 104615_20090203101235/Rendered/PDF/JO010ERfKE0II01aisal0Stage010Jan.28.pd f.

28. http://www.jordaninvestment.com/JordanataGlance/PeopleTalent/tabid/76/language/e n-US/Default.aspx

29. "United Nations Relief and Works Agency(UNRWA)". http://www.un.org/unrwa/programmes/education/index.html.

30. http://www.roughguides.com/website/travel/Destination/content/default.aspx?titleid= 87\&xid=idh124603328_0006

31. "World Bank 2009."Higher Education Reform for the Knowledge Economy Project." Project Appraisal Document. World Bank. Washington, DC". http://www-wds.worldbank.org/external/default/WDSContentServer/WDSP/IB/2009/ 04/30/000350881_20090430095054/Rendered/PDF/468230PAD0P102101Official0U se0Only1.pdf.

32. "World Bank. 2009. "Education Reform for the Knowledge Economy II." Project Information Document. World Bank, Washington ,DC". http://www-wds.worldbank.org/external/default/WDSContentServer/WDSP/IB/2009/ 05/04/000333038_20090504003729/Rendered/PDF/468240PAD0P105101Official0U se0Only1.pdf.

33. "World Bank 2009."Higher Education Reform for the Knowledge Economy Project." Project Appraisal Document. World Bank. Washington, DC". http://www-wds.worldbank.org/external/default/WDSContentServer/WDSP/IB/2009/ 05/04/000333038_20090504003729/Rendered/PDF/468240PAD0P105101Official0U se0Only1.pdf. 